The Geographical Journal of Nepal

Vol. 11: 77-94, 2018

Central Department of Geography,

Tribhuvan University, Kathmandu, Nepal

\title{
Land use land cover change and its pathways in Sidin VDC, Panchthar district, Nepal
}

\author{
Prem Sagar Chapagain ${ }^{1 *}$; Mohan Kumar Rai'; and Basanta Paudel ${ }^{2}$ \\ ${ }^{1}$ Central Department of Geography, Tribhuvan University, Kathmandu, Nepal; \\ ${ }^{2}$ Institute of Geographic Sciences and Natural Resources Research, CAS, Beijing \\ 100101, China.
}

(*Corresponding Author: ps.chapagain@gmail.com )

Land use/land cover situation is an important indicator of human interaction with environment. It reflects both environmental situation and the livelihood strategies of the people in space over time. This paper has attempted to study the land usel land cover change of Sidin VDC, in the Koshi River basin in Nepal, based on maps and Remote sensing imageries (RS) data and household survey using structured questionnaires, focus group discussion and key informant interview. The study has focused on analysis the trend and pathways of land use change by dividing the study area into three elevation zones - upper, middle and lower. The time series data analysis from 1994-2004-2014 show major changes in forest and agricultural land. The dominant pathways of change is from forest to agriculture and forest to shrub during 1994-2004 and agriculture to forest during 20042014. The development of community forest, labor migration and labor shortage are found the major causes of land use change.

Keywords: Land use change; GIS/RS; agriculture; forest; pathways; Koshi River basin; Panchthar; Koshi basin.

\section{Introduction}

Land cover is the bio-physical state of land while land use refers to the purpose for which land is used (Steffen et al., 1992; Turner et al., 1995). Land-use / land-cover (LULC) change is the main driver of global environmental change and it is central to the sustainable development debate. It affects a broader array of environmental and landscape attributes such as quality of water, land and air resources, ecosystem processes and function, and the climate system (Lambin et al., 2000). Land is basic natural resource 
to human beings and therefore it plays a strategic role in the determination of economic, social and cultural development of human beings (Vink, 1975).

There are limited research on land use/land cover change at national scale in Nepal though there are many at regional scale and watershed level. The historical data on land use particularly forest coverage has been provided by various forest surveys. The forest coverage of the country was about 45 percent in 1964 that was decreased to 38 percent in 1978/89, 36 percent in 1984, 29 percent in 1994 (DFRS 2015 cited in Chapagain 2017). The latest forest survey of Nepal has shown 40 percent forest area of the country (ibid). However, there are a number of studies at micro level from the various parts of the country that deal on land use trend, its causes and the pathways (Paudel et al., 2017; Bajracharya, 1983; Mahat, 1985; Virgo and Subba, 1994; Shrestha and Brown, 1995; Khanal, 2002; Sharma, 2003; Khanal and Watanabe, 2006; Bajracharya et al., 2014; Rimal et al., 2015). The explanations of drivers of land use change have been changing over the time. The high rate of forest land degradation and an increase in agricultural land during1970s was reported due to high population growth that demanded land for cultivation (Eckholm, 1976; Collins and Jenkins, 1996). Later, Ives and Messerli (1989) pointed out the bio-physical, climatic and historical processes as the major drivers of land use change. The increasing poverty, lack of livelihood opportunities, and several forest based economic activities have caused forest degradation and have had an adverse effect on the environment in Nepal Himalaya (Gurung, 1981, 2005; Paudel et al., 2016b; Koirala, 2017). The study on LULC change from the Koshi basin in Nepal also shows population as a major driver of expanding agricultural land in last three decades (Paudel et al., 2016a). Similar findings are also reported by satellite imagery-based mapping conducted in 2000 (Sharma et al., 2000) and in 2012 (Gao, 2012) in the Koshi basin. Land is an important property and economic resource where all the development activities are concentrated. A better understanding of process of land use change and their influence on landscape is essential for rational management of land resources and environment (Gurung and Khanal, 1986-88), therefore, this paper aims to examine the changing land use trend, its pathways, and causes at micro scale that can provide a comparative insight to the studies done at watershed and regional level.

\section{Methods and materials}

\section{Study area}

The study area is in the Koshi River basin, located in the north- eastern part of Panchthar district of Nepal. It is 30 kilometer $(\mathrm{km})$ north-east from the district headquarters (Phidim) and bordered with India in the eastern side. The area lies in between $27^{\circ} 06^{\prime}$ and $27^{\circ} 11^{\prime}$ north latitude, $87^{\circ} 51^{\prime}$ and $87^{\circ} 59^{\prime}$ 'east longitude. The total area of the VDC is 
$59.03 \mathrm{~km}^{2}$ (5902.81 ha) and ranges from 1045 meters above sea level to 3586 meters. For the analysis, the study area is divided into three elevation zones - upper, middle and lower. The upper part is above 2100 meters, the middle part is from 1700 to 2100 meters and the lower part is below 1700 meters elevation from the mean sea level (msl) (Figure 1).

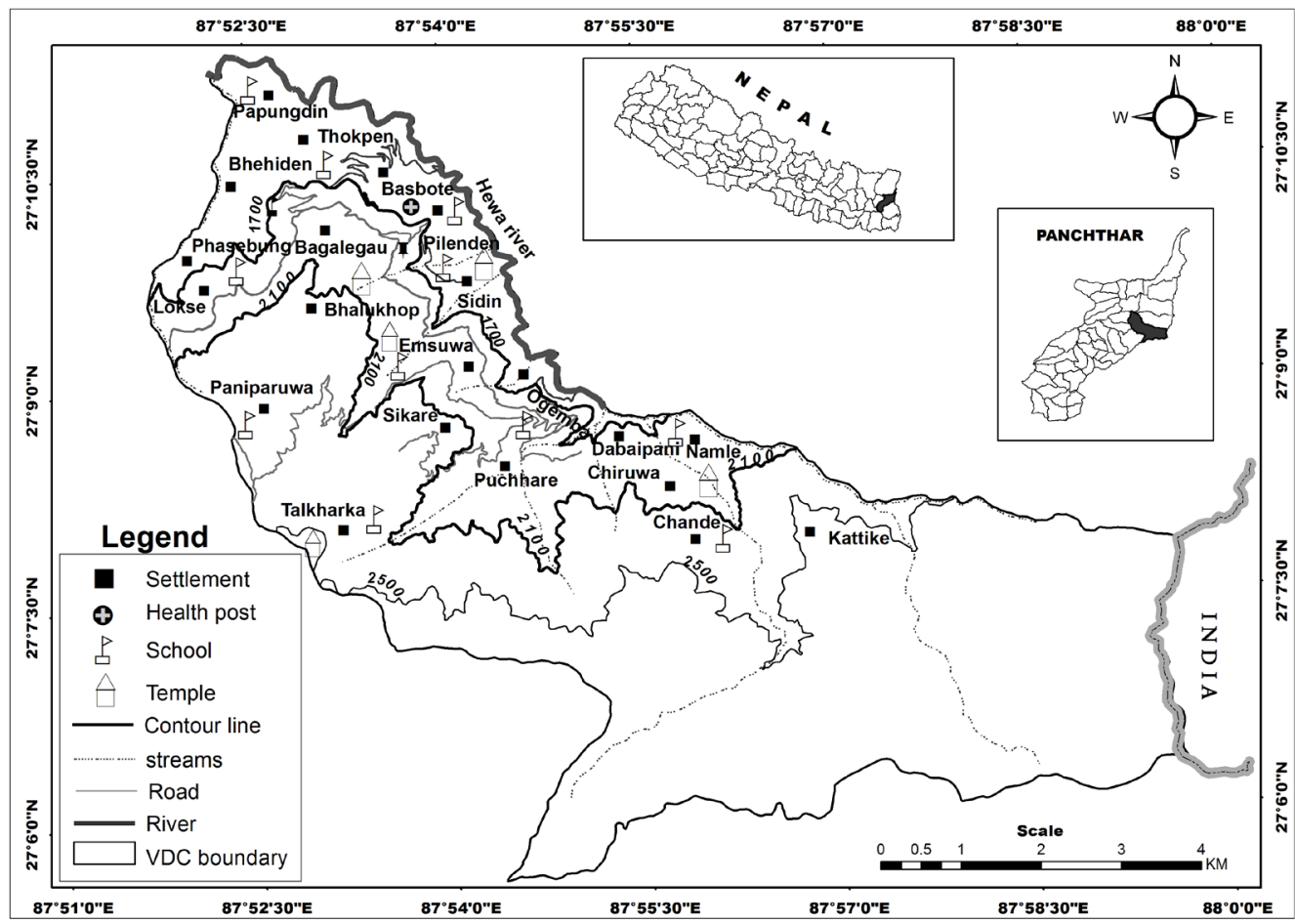

Figure 1: Location of the study area.

The three micro regions is divided based on agro-ecology and cultural practices (also see Guillet, 1983). Rice and maize is cultivated in the lower part and it is inhibited by mixed population of caste and ethnic groups such as Chhetree, Brahman and Limbu; maize and millet are grown in middle part and it is inhabited by Limbu and Rai; and the upper part is inhibited by Rai and Gurung where they mainly cultivate potato, maize and peas. Out of total area, the upper part covers about 69 percent followed by 19 percent in middle and 12 percent in lower part. Though the area is small there is high variation in the landscapes, as some flat land in lower belt, gentle north-eastern aspect of slope in middle part and steep slope land area in upper part (Figure 1). There are 885 households and 4588 population of the study area (CBS, 2012). Agriculture is the major economy. Local breed livestock such as cow, goat, and ox are mainly nurtured for food and draught power. 
The study is based on analysis of maps and socio-economic data collected from primary and secondary sources. The time series land use pattern and land use change is captured based on topographical maps of 1994 (2687-16a, 16b, 16d) of 1:25000 scale produced by Department of Survey, Government of Nepal. The land use pattern of 2004 and 2014 is derived by updating the 1994 maps by using google earth. While working different scale maps there might have been some error which has tried to verify during field verification. These three data sets are analyzed in GIS. The detail analysis of land use change by elevation zones is given in Tables. The land use situation of the particular year and the changes from 1994-2004 and 1994-2014 are mapped taking the major land use categories such as agriculture, forest and shrub/bush. Importantly, land use change from forest to agriculture is important one. Special focus has given in mapping changes from forest to cardamom. Cardamom cultivation area also observed as forest area because it needs shades of trees and bushes. So such area has been verified and mapped. River, grass land, road and public use land are the other land use categories which have very small area that cannot been properly read while showing on the map.

The causes of landuse change are derived from household survey. About 10 percent ( 80 households) of the total households were proportionately selected as the sample households. These households were selected from the three different elevation zones covering households of all caste and ethnic groups of the VDC. Out of total households (885), there were 274 households in upper part, 390 in middle and 221 in lower part so about 10 percent of the total households i.e. 25, 35 and 20 households were randomly selected from each part respectively. Using the household questionnaires, it was asked about the major causes of land use change and other demographic and socioeconomic characteristics of the households. Furthermore, we also did three focus group discussions, one from each of the elevation zone, to know causes of land use change and its pathways. In addition, available socio-economic and other information are collected from various sources such as Central Bureau of Statistics (CBS), District Forest Office (DFO), and Village Development Committee (VDC).

\section{Results and discussion}

\section{Land use/land cover situation and its spatial distribution}

There are seven different types of land cover in the study area. Among them forest, agricultural and shrub/bush are the three major types of land uses. Forest is the dominant land use type that has covered about 70 percent followed by agricultural $(22.8 \%)$ and shrub land (5.8\%) in 2014 (Table 1). It comprises both private forest and community forest that have been entrusted to forest user groups for development, conservation and utilization in the interest of the community.

|| 80 || 
P. S. Chapagain; M. K. Rai; B. Paudel / The Geographical Journal of Nepal Vol. 11: 77-94, 2018

Table 1: Land use Land cover types and area of Sidin, VDC 1994, 2004 and 2014

\begin{tabular}{|c|c|c|c|c|c|c|c|c|}
\hline \multirow{2}{*}{ S.n } & \multirow{2}{*}{$\begin{array}{l}\text { Land use } \\
\text { type }\end{array}$} & \multirow{2}{*}{$\begin{array}{l}\text { Part of VDC } \\
\text { (Elevation zone) }\end{array}$} & \multicolumn{2}{|c|}{1994} & \multicolumn{2}{|r|}{2004} & \multicolumn{2}{|r|}{2014} \\
\hline & & & Area(ha) & $\%$ & Area(ha) & $\%$ & Area(ha) & $\%$ \\
\hline \multirow{5}{*}{1} & \multirow{4}{*}{ Forest } & Upper & 3334.62 & 83.02 & 3385.38 & 87.32 & 3410.60 & 82.06 \\
\hline & & Middle & 450.76 & 11.22 & 353.87 & 9.13 & 488.68 & 11.76 \\
\hline & & Lower & 231.17 & 5.76 & 137.66 & 3.55 & 257.05 & 6.18 \\
\hline & & Total & 4016.55 & & 3876.91 & & 4156.33 & \\
\hline & & Percent to grand total & & 68.04 & & 65.68 & & 70.41 \\
\hline \multirow{5}{*}{2} & \multirow{4}{*}{$\begin{array}{l}\text { Agriculture } \\
\text { land }\end{array}$} & Upper & 427.46 & 28.06 & 202.92 & 13.63 & 315.89 & 23.46 \\
\hline & & Middle & 650.04 & 42.67 & 747.10 & 50.20 & 615.15 & 45.68 \\
\hline & & Lower & 445.88 & 29.27 & 538.35 & 36.17 & 415.71 & 30.87 \\
\hline & & Total & 1523.38 & & 1488.37 & & 1346.75 & \\
\hline & & Percent to grand total & & 25.81 & & 25.21 & & 22.82 \\
\hline \multirow{5}{*}{3} & \multirow{4}{*}{$\begin{array}{l}\text { Shrub and } \\
\text { bushes }\end{array}$} & Upper & 235.05 & 100.00 & 463.83 & 98.98 & 345.63 & 100.00 \\
\hline & & Middle & & & 4.80 & 1.02 & & \\
\hline & & Lower & & & & & & \\
\hline & & Total & 235.05 & & 468.63 & & 345.63 & \\
\hline & & Percent to grand total & & 3.98 & & 7.94 & & 5.86 \\
\hline \multirow{3}{*}{4} & \multirow{2}{*}{ River } & Lower & 26.72 & 100.00 & 28.55 & 100.00 & 27.48 & 100.00 \\
\hline & & Total & 26.72 & & 28.55 & & 27.48 & \\
\hline & & Percent to grand total & & 0.45 & & 0.48 & & 0.47 \\
\hline \multirow{5}{*}{5} & \multirow{4}{*}{$\begin{array}{l}\text { Grass } \\
\text { land }\end{array}$} & Upper & 83.67 & 82.75 & 28.10 & 69.64 & 25.35 & 95.23 \\
\hline & & Middle & 17.44 & 17.25 & 12.25 & 30.36 & 1.27 & 4.77 \\
\hline & & Lower & & & & & & \\
\hline & & Total & 101.11 & & 40.35 & & 26.62 & \\
\hline & & Percent to grand total & & 1.71 & & 0.68 & & 0.45 \\
\hline \multirow{5}{*}{6} & \multirow{4}{*}{ Road } & Upper & & & & & 2.76 & 14.68 \\
\hline & & Middle & & & & & 12.87 & 68.46 \\
\hline & & Lower & & & & & 3.17 & 16.86 \\
\hline & & Total & & & & & 18.80 & \\
\hline & & Percent to grand total & & & & & & 0.32 \\
\hline \multirow{6}{*}{7} & \multirow{4}{*}{ Public use } & Upper & & & 0.52 & 30.77 & 0.58 & 23.58 \\
\hline & & Middle & & & 0.97 & 57.40 & 1.53 & 62.20 \\
\hline & & Lower & & & 0.20 & 11.83 & 0.35 & 14.23 \\
\hline & & Total & & & 1.69 & & 2.46 & \\
\hline & & Percent to grand total & & & & 0.03 & & 0.04 \\
\hline & \multicolumn{2}{|c|}{ Grande Total } & 5902.81 & 100.00 & 5902.81 & 100.00 & 5902.81 & 100.00 \\
\hline
\end{tabular}

Source: Topographical maps and google images. 
During the field survey, it has observed that agriculture land covers both irrigated land and rain-fed terrace. Agriculture is the main occupation of the local people. Slash and burn farming was the dominant before 1990 especially in the upper part and it has still practiced by a few farmers. The farming of large cardamom has started after 1990 in the wet land areas along the streams and in the slope land of the middle part where irrigation is available in the winter. Shrub/bushes is another important land cover of the study area which mostly lies in upper part and very few in middle belt. Grassland is found in upper and middle part of the study area. Road construction is a new phenomenon that has appeared in 2014. River (Hewa) and public use land (area covered by various institutions such as school, temple, and health-post) are the other types of land uses in the study area (Table 1, Figure 2).

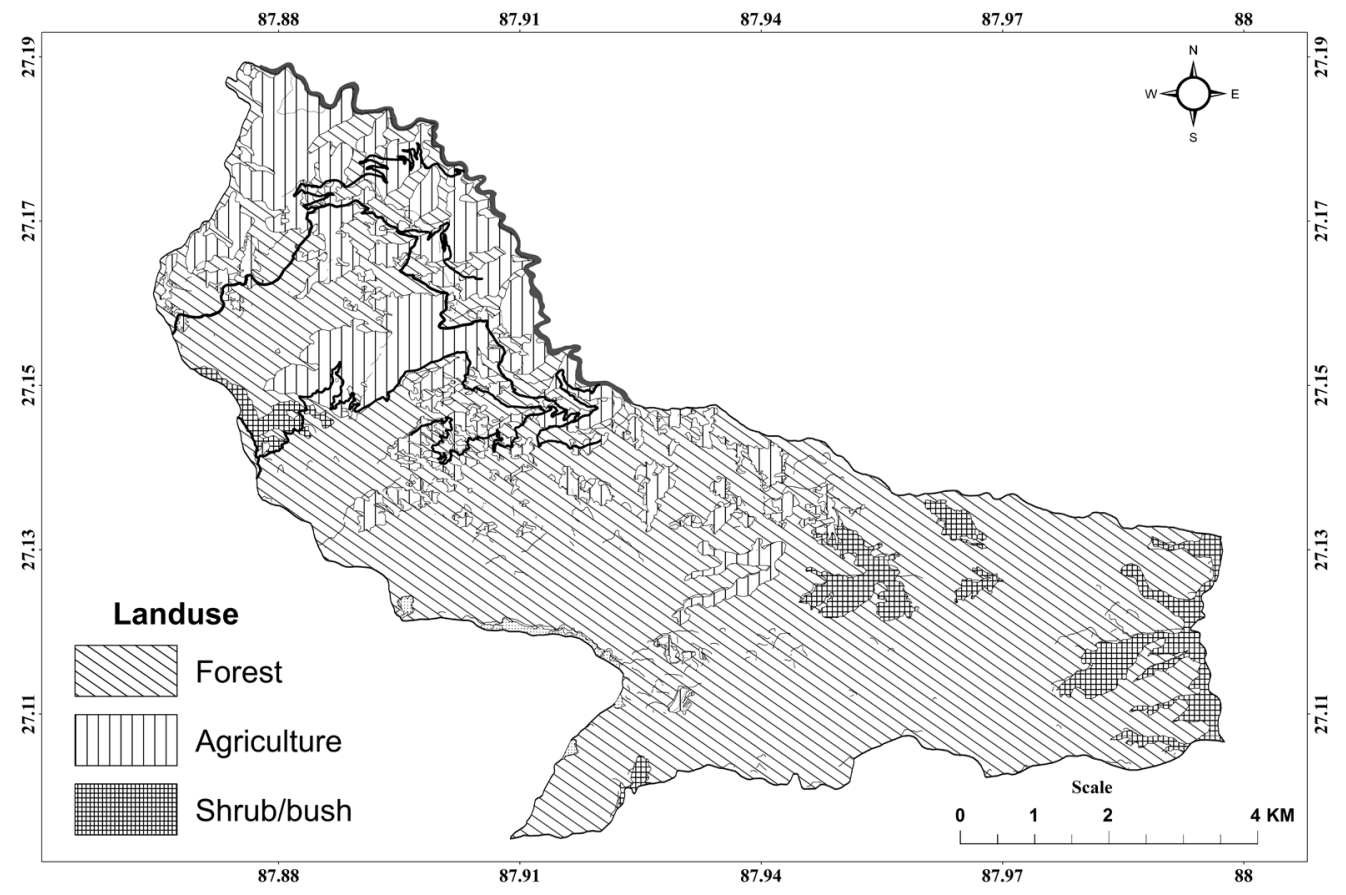

Figure 2: Major land use land cover types of Sidin VDC, 2014.

Similar to the year of 2014, forest, agriculture and shrub/bush were the major land cover types in 2004 that covered about 66 percent, 25 percent and about 8 percent area of the VDC respectively. In 2004, forest was dominantly distributed in upper and middle parts (Rai, 2015). Agricultural land was mostly dominated in middle and lower part and the shrub land was in the upper. Public use land also appeared in 2004 (Table 1 and Figure 3). 


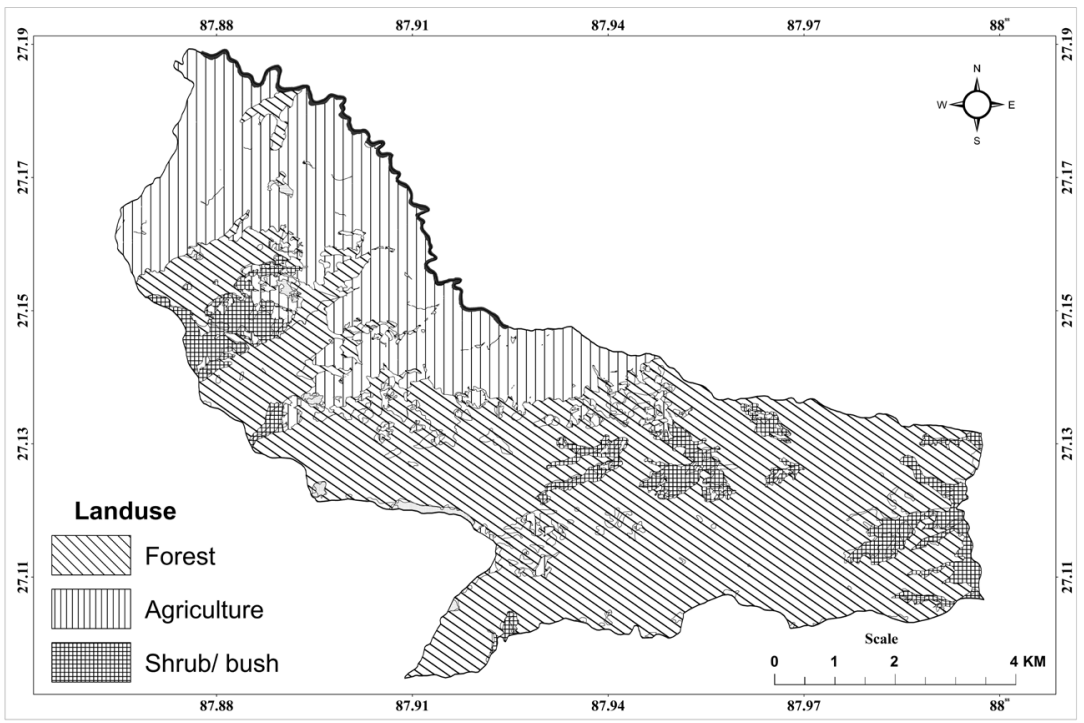

Figure 3: Major land use land cover types of Sidin VDC, 2004

There were only five types of land cover in 1994. Road and public use lands were not there in 1994. Forest, agricultural, shrub/bush and grass land were the major three types of land uses that had covered 68 percent, about 26 percent, about 4 percent and 1.7 percent of the total area respectively (Table 1, Figure 4).

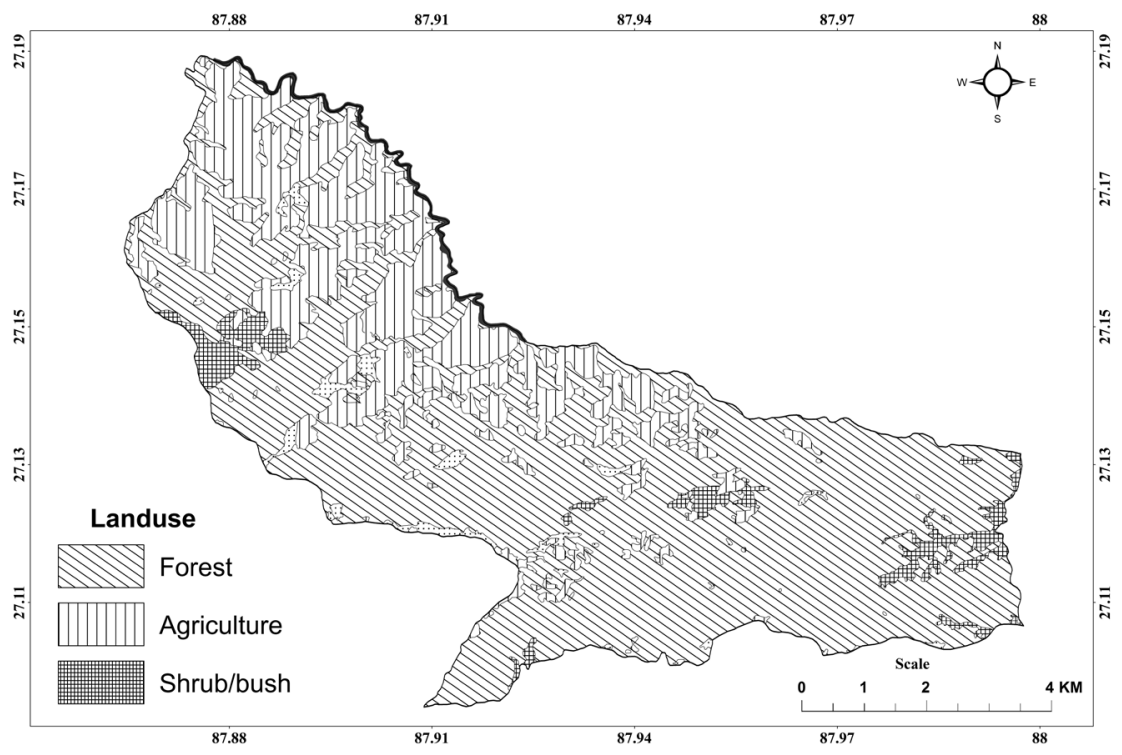

Figure 4: Major land use land cover types of Sidin VDC, 1994. 


\section{Land use and land cover change}

Land use and land cover is an important component in understanding the interactions of the human activities with the environment. During the period of 1994-2014, there has been a lot of changes in the land use/land cover pattern in Sidin VDC. Major changes have observed in forest, agriculture and shrub land. During 1994-2004, forest cover has decreased by 3.6 percent (139.64 ha). Similarly the shrub/bushes has increased by about 50 percent ( $232.91 \mathrm{ha}$ ). Agricultural land has also decreased by about 2.3 percent (467.96 ha) and grass land has decreased by 150.5 percent (60.76 ha). A significant change has observed in decreases in forest coverage in middle and lower part. It is mainly due to the cultivation of large cardamom (Table 2, Figure 5).

Table 2: Land use land cover change of Sidin VDC, 1994-2014

\begin{tabular}{|c|l|r|r|r|r|r|r|}
\hline \multirow{2}{*}{ sl.no } & \multirow{2}{*}{ Land use type } & \multicolumn{6}{|c|}{ Years } \\
\cline { 3 - 8 } & & \multicolumn{2}{|c|}{$1994-2004$} & $2004-2014$ & \multicolumn{2}{|c|}{$1994-2014$} \\
\cline { 3 - 8 } & & Area (ha) & $\%$ & Area (ha) & $\%$ & Area (ha) & $\%$ \\
\hline 1 & Forest & -139.64 & -3.6 & 279.42 & 6.72 & 139.78 & 3.36 \\
\hline 2 & Agriculture & -35.01 & -2.35 & -141.62 & -10.52 & -176.63 & -13.12 \\
\hline 3 & Shrub/bushes & 232.91 & 49.84 & -123.00 & -35.59 & 110.58 & 31.99 \\
\hline 4 & Grassland & -60.76 & -150.58 & -13.73 & -51.58 & -74.49 & -279.83 \\
\hline 5 & River & 1.83 & 6.41 & -1.07 & -3.89 & 0.76 & 2.77 \\
\hline 6 & Public use & 1.69 & 100 & 0.77 & 31.3 & 2.46 & 100 \\
\hline 7 & Road & & & 18.80 & 100 & 18.8 & 100.00 \\
\hline
\end{tabular}

Source: Analysis based on Table 1.

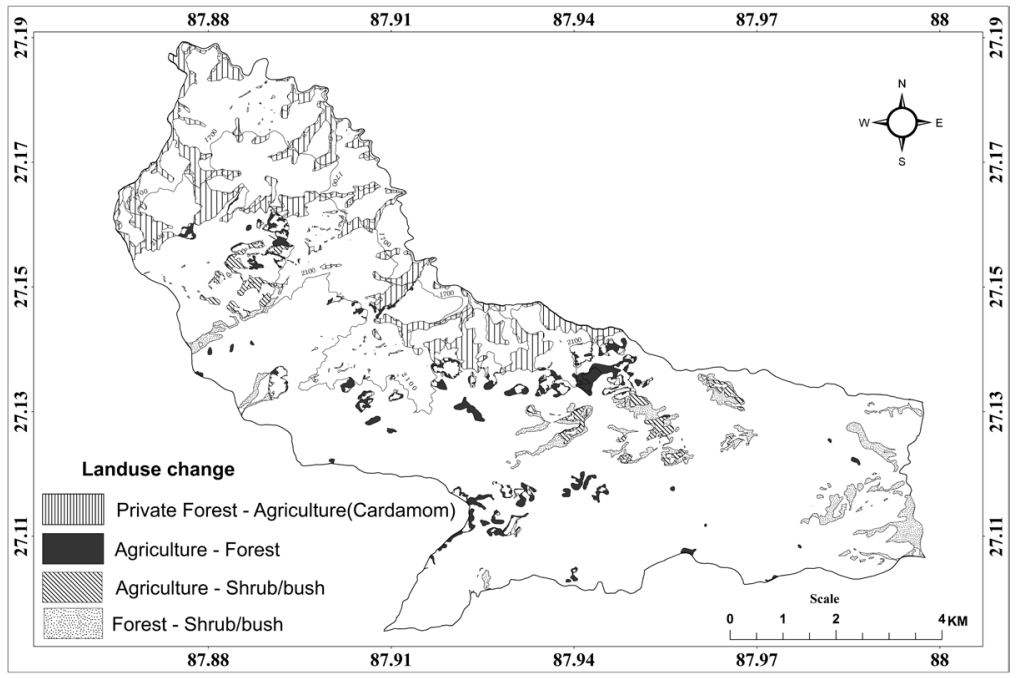

Figure 5: Landuse change 1994-2004. 
Unlike to the trend of 1994-2004, forest coverage has increased in the period of 2004 - 2014. In this period forest has increased by 6.72 percent ( $279.42 \mathrm{ha}$ ) followed by an increases in public land use with 0.77 ha. Unlike previous period, many diseases appeared to large cardamom and the cardamom grown area again converted to private forest and thus forest coverage has increased both in middle and lower part during this period. Infrastructure development such as road has appeared in this period. Following the trend of the previous decade, both agricultural land and shrub/bushes land have decreased by 10.52 percent (141.62 ha) and 35.59 percent (123.0 ha) respectively. Similarly, grassland has decreased by 13.73 ha (51.58\%) in this period (Table 2, Figure 6).

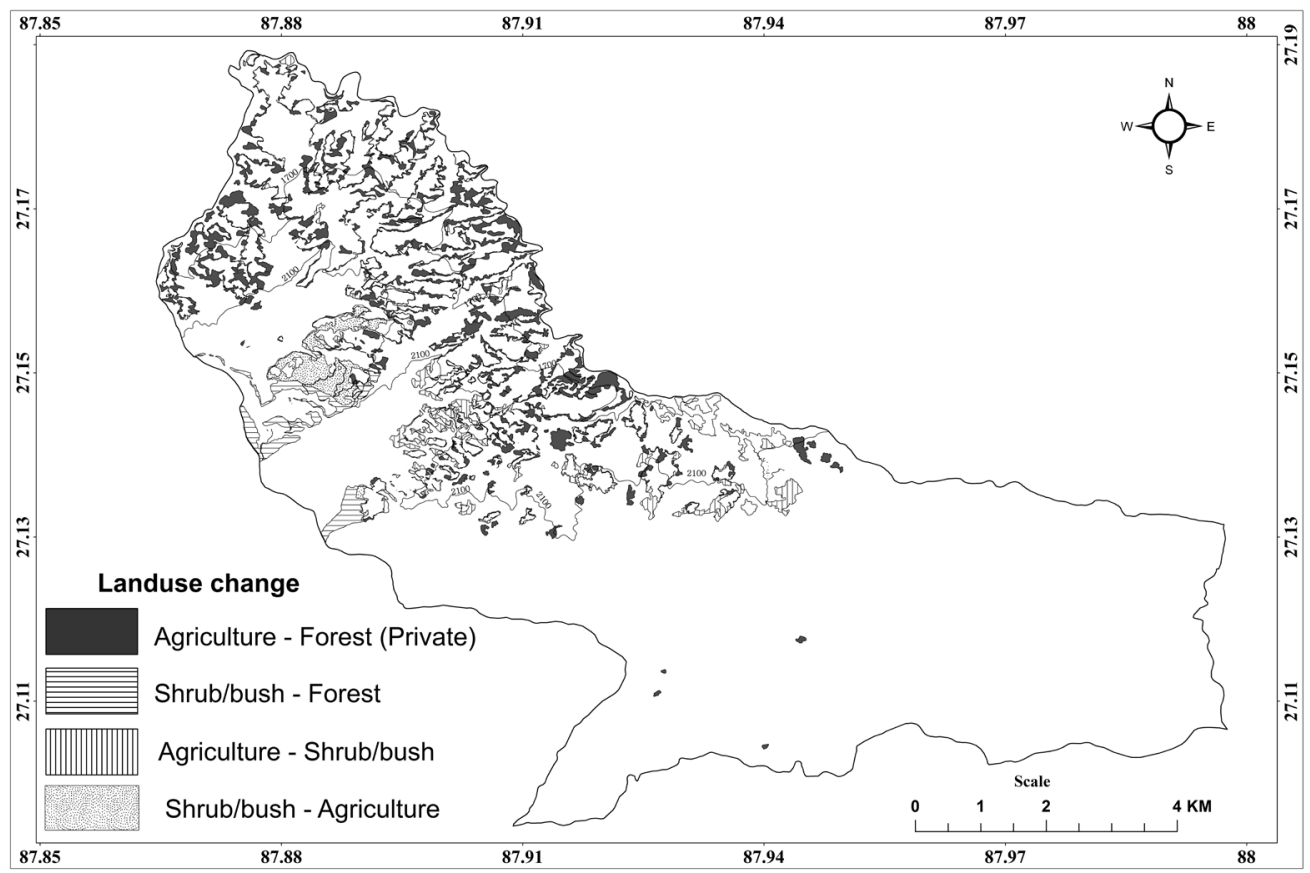

Figure 6. Landuse change 2004-2014

In totality from 1994-2014, forest coverage has increased and decreases in agricultural land is quite contrary to the claiming of Eckholm (1976). Such changes somehow follow the trend in Ilam (Chapagain, 2006) and Dhankuta district (Virgo and Subba, 1994) where forest coverage has increased. Between the period of 1978-1996, it has noticed increases in forest cover in the Mardi and Fewa watersheds in Pokhara Valley of Western Nepal and decreases in shrub and rain-fed agriculture mainly due to foreign labor migration (Awasti et al., 2002). A temporal study from 1976-1989-2000 from the Roshi watershed, Kavre district in Central Nepal also shows increases in forest land and decreases in shrub, grass and upland agriculture (Gautam et al., 2003). 


\section{Pathways of land use and land cover change}

The major pathways of land use change are to and from agriculture-forest-bush in both periods i.e. 1994-2004 and 2004-2014. As given in Table 3, changes from forest to agriculture are very dominant as 360.69 ha has changed. It is mainly due to the change from existing private forest to cardamom cultivation. All together 338.96 hectares of private forest has been brought under cardamom cultivation in between 1994-2004. Out of it, $59 \%$ lies in middle part and $41 \%$ lies in lower part. Land use change from agriculture to forest (239 ha) has been observed as the second dominant pathways of land use change.Similarly, agriculture to shrub (166 ha) and forest to bush (114ha) has been the third and fourth most dominant pathway followed by grass to forest (74.6 ha), shrub/bush to forest (42 ha), and agriculture to grass (16.6 ha) (Table 3, Figure 7).

Table 3: Pathways of land use land cover change of Sidin VDC, 1994-2004

\begin{tabular}{|c|c|c|c|c|c|c|}
\hline \multirow{2}{*}{ S.N. } & \multirow{2}{*}{ Pathways } & \multicolumn{3}{|c|}{$\begin{array}{l}\text { Area (in ha) by elevation } \\
\text { zone (part) }\end{array}$} & \multirow{2}{*}{$\begin{array}{l}\text { Total } \\
\text { area } \\
\text { (ha) }\end{array}$} & \multirow{2}{*}{$\begin{array}{l}\% \text { to } \\
\text { total }\end{array}$} \\
\hline & & $\begin{array}{l}\text { Upper } \\
\text { part }\end{array}$ & $\begin{array}{l}\text { Middle } \\
\text { part }\end{array}$ & $\begin{array}{l}\text { Lower } \\
\text { part }\end{array}$ & & \\
\hline 1 & Forest-Agriculture (cardamom) & 21.73 & 198.95 & 140.01 & 360.69 & 34.61 \\
\hline 2 & Agriculture-Forest & 237.05 & 2.35 & & 239.4 & 22.97 \\
\hline 3 & Agriculture-Shrub/bushes & 160.72 & 5.52 & & 166.24 & 15.95 \\
\hline 4 & Forest-Shrub/bushes & 112.68 & 1.61 & & 114.29 & 10.97 \\
\hline 5 & Grass - Forest & 63.99 & 10.63 & & 74.62 & 7.16 \\
\hline 6 & Agriculture-Grass & 10.23 & 6.45 & & 16.68 & 1.60 \\
\hline 7 & Grass - Agriculture & 3.52 & 4.25 & & 7.77 & 0.75 \\
\hline 8 & Forest-River & & & 4.85 & 4.85 & 0.47 \\
\hline 9 & Forest-Grass & 2.7 & 2.12 & & 4.82 & 0.46 \\
\hline 10 & Shrub/bush-Agriculture & & 4.08 & & 4.08 & 0.39 \\
\hline 11 & River-Agriculture & & & 2.01 & 2.01 & 0.19 \\
\hline 12 & Shrub/bush-Forest & 40.2 & 2.01 & & 42.21 & 4.05 \\
\hline 13 & River-Forest & & & 1.88 & 1.88 & 0.18 \\
\hline 14 & Agriculture-Public & 0.4 & 0.92 & 0.2 & 1.52 & 0.15 \\
\hline 15 & Agriculture-River & & & 0.87 & 0.87 & 0.08 \\
\hline 16 & Forest-Public & 0.17 & & & 0.17 & 0.02 \\
\hline 17 & Shrub/bush-Grass & 0.12 & 0.01 & & 0.13 & 0.01 \\
\hline 18 & Total & 653.51 & 238.9 & 149.82 & 1042.23 & 100.00 \\
\hline
\end{tabular}


While in totality, forest and agricultural land have 139.6 ha and 35 ha respecively. Grass land has also decreased by 60.7 ha. However, shrub/bush has increased by 232.2 ha. during the period of 1994-2004. The loss of agricultural land is transfered to forest, shrub and grass land. It has observed a major change from forest to agricultural land and shrub (Figure 7).

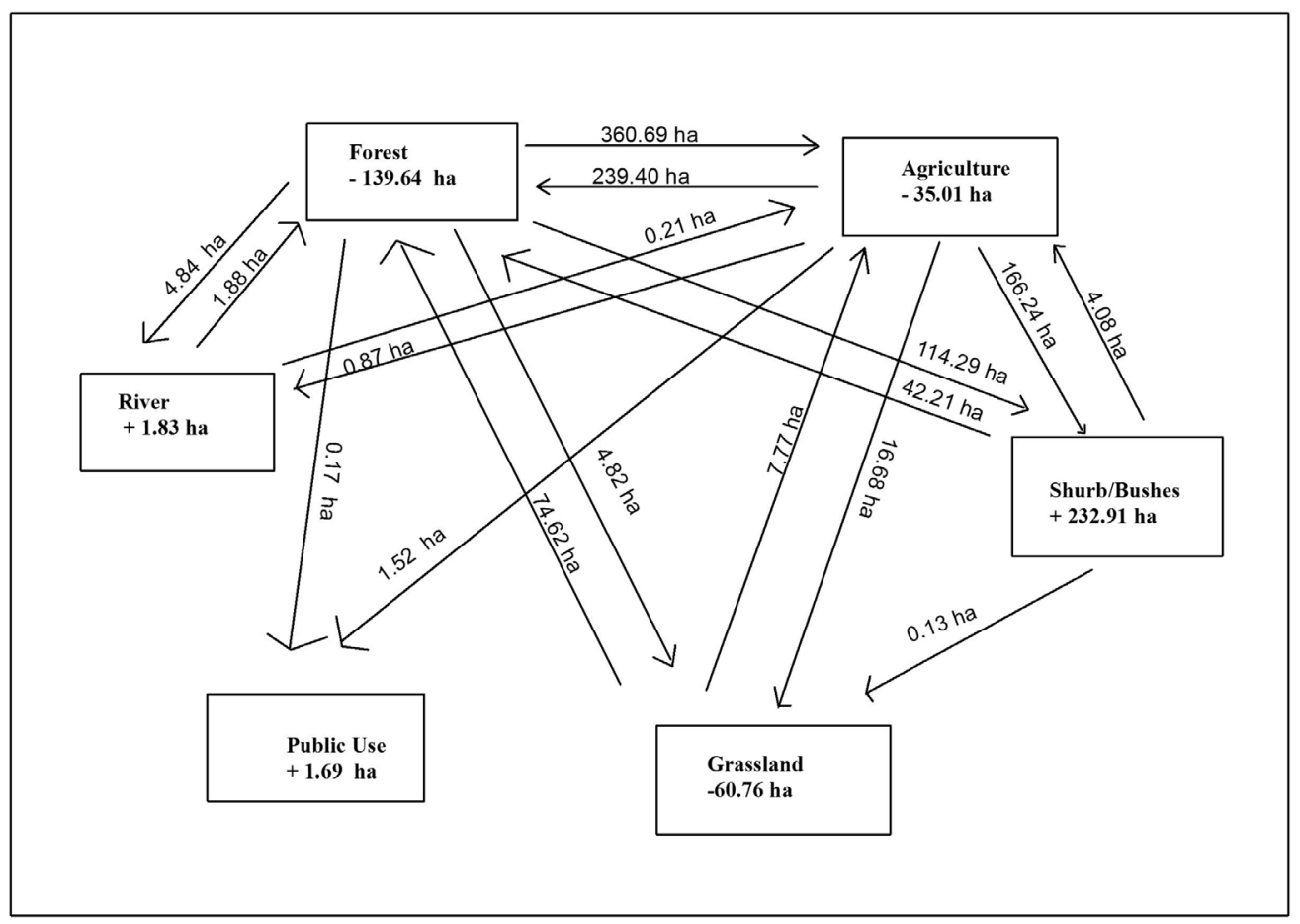

Figure 7: Pathways of land use land cover change in Sidin VDC, 1994-2004

Land cover change from shrub/bush to forest (135.6 h) has been observed as the major pathway during the period of 2004-2014. It is followed by chnages from agriculture to forest $(118.1 \mathrm{ha})$. The third and fourth pathways of change have been observed from agriculture to bush (50.8 ha), and shrub/bush to agriculture (40.4 ha) respectively. Similarly, about 18 hectares of grassland has converted to forest and 11 ha from agriculture to road (Table 4, Figure 8). 
P. S. Chapagain; M. K. Rai; B. Paudel / The Geographical Journal of Nepal Vol. 11: 77-94, 2018

Table 4: Pathways of land use land cover change of Sidin VDC, 2004-2014

\begin{tabular}{|c|c|c|c|c|c|c|}
\hline \multirow{2}{*}{ S.N. } & \multirow{2}{*}{ Pathways } & \multicolumn{3}{|c|}{$\begin{array}{l}\text { Area (in ha) by elevation } \\
\text { zone (part) }\end{array}$} & \multirow{2}{*}{$\begin{array}{l}\text { Total } \\
\text { area } \\
\text { (ha) }\end{array}$} & \multirow{2}{*}{$\%$ total } \\
\hline & & $\begin{array}{l}\text { Upper } \\
\text { part }\end{array}$ & $\begin{array}{l}\text { Middle } \\
\text { part }\end{array}$ & $\begin{array}{l}\text { Lower } \\
\text { part }\end{array}$ & & \\
\hline 1 & Shrub/bush-Forest & 135.67 & & & 135.67 & 33.41 \\
\hline 2 & Agriculture - Forest & 115.17 & 2.01 & 1.01 & 118.19 & 29.10 \\
\hline 3 & Agriculture-Shrub/bushes & 50.86 & & & 50.86 & 12.52 \\
\hline 4 & Shrub/bush- Agriculture & 40.37 & & & 40.37 & 9.94 \\
\hline 5 & Grass-Forest & 7.24 & 10.46 & & 17.70 & 4.36 \\
\hline 6 & Agriculture -Road & 1.44 & 8.14 & 2.16 & 11.74 & 2.89 \\
\hline 7 & Forest-Road & 1.14 & 4.73 & 1.01 & 6.88 & 1.69 \\
\hline 8 & Forest-Agriculture & 2.38 & 2.12 & 1.07 & 5.57 & 1.37 \\
\hline 9 & Forest-Grassland & 5.32 & 0.02 & & 5.34 & 1.31 \\
\hline 10 & Forest-Shrub/bushes & 5.18 & & & 5.18 & 1.28 \\
\hline 11 & Grass-Agriculture & 0.55 & 1.51 & & 2.06 & 0.51 \\
\hline 12 & River-Forest & & & 1.77 & 1.77 & 0.44 \\
\hline 13 & Forest-River & & & 1.80 & 1.80 & 0.44 \\
\hline 14 & River-Agriculture & & & 1.21 & 1.21 & 0.30 \\
\hline 15 & Agriculture-Grass & 0.64 & 0.05 & & 0.69 & 0.17 \\
\hline 16 & Forest-Public Use & 0.04 & 0.50 & & 0.54 & 0.13 \\
\hline 17 & Shrub/bush-Road & 0.18 & & & 0.18 & 0.04 \\
\hline 18 & Agriculture -Public Use & 0.02 & 0.16 & 0.05 & 0.23 & 0.06 \\
\hline 19 & Agriculture-River & & & 0.11 & 0.11 & 0.03 \\
\hline 20 & Total & 366.20 & 29.70 & 10.19 & 406.09 & 100.00 \\
\hline
\end{tabular}

Unlike to the earlier period (1994-2004), forest land has gained 279 hectares and it is mainly contributed by shrub, agricultural land, and grass land. While agricultural land has lost its coverage by about 142 hectares. The major pathways of agricultural land loss remains to forest, shrub and road respectively (Figure 8). 


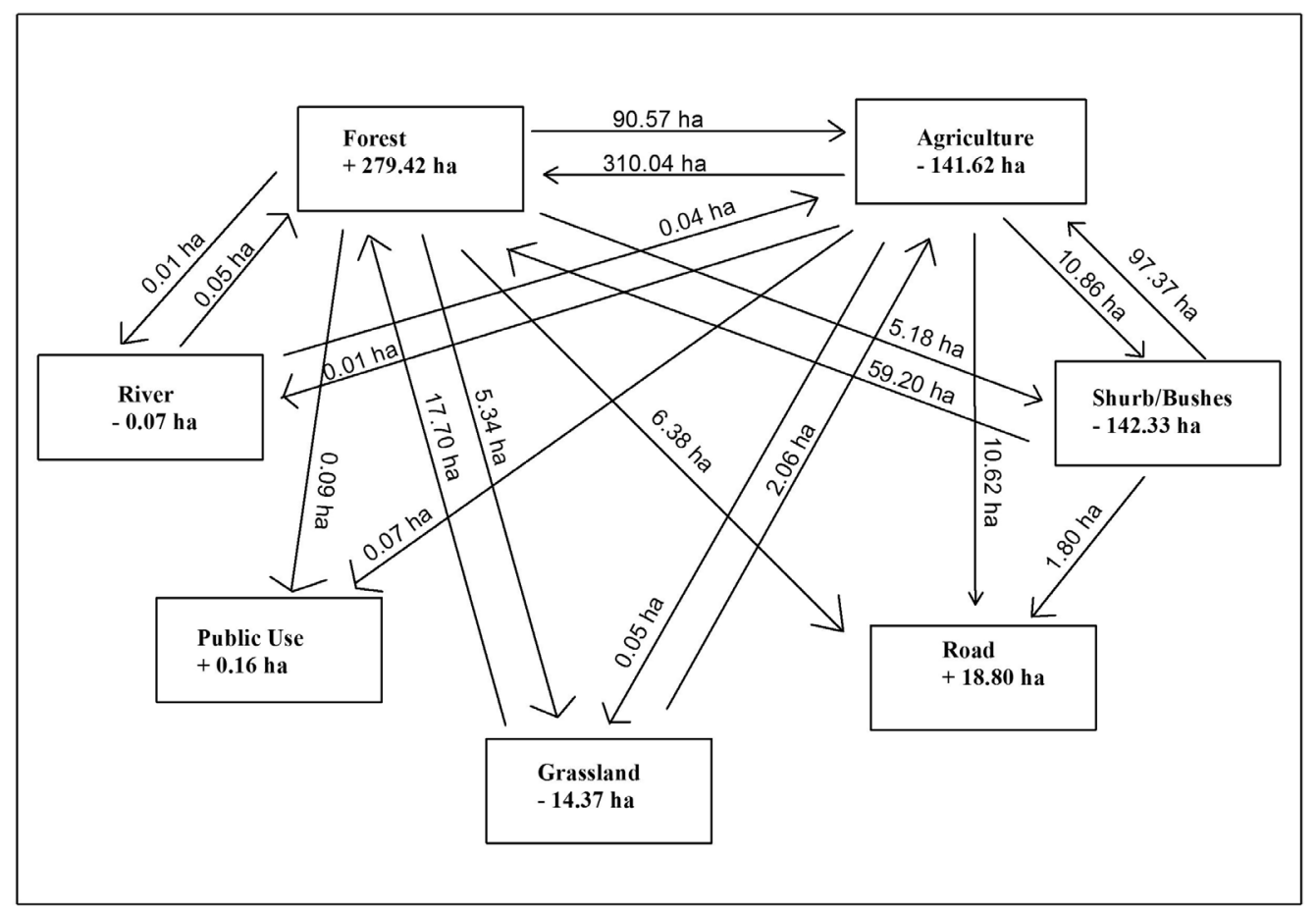

Figure 8: Pathways of land use land cover change in Sidin VDC, 2004-2014.

\section{Drivers of land use and land cover change}

Land use/ land cover is highly dynamic and also have significant internal trading among the land-use types. Studies on land use change from various parts of Nepal show different causes of land use change. Many studies from Midhill region of Nepal have reported migration and land abandonment, change in land tenure policy, urbanization and the population pressure as the major drivers of land use change (Paudel et al., 2017; Virgo and Subba, 1994; Shrestha and Brown, 1995; Khanal, 2002; Sharma, 2003; Khanal and Watanabe, 2006; Bajracharya et al., 2014; Rimal et al., 2015). The traditional smallscale subsistence farmers who were not able to generate adequate income to meet household demands choose foreign labor migration and they have gradually abandoned agriculture land. Furthermore, the socio-political instability, availability of off-farm income in cities, decreasing agriculture productivity, labor shortage, inadequate income from farming and geographical proximity to cities have become the major drivers of land abandonment that resulted land use change (Paudel et al., 2012; Paudel et al., 2014, Tamang et al., 2014). In Roshi watershed in Kavre district in Central Nepal, land use change is driven by the development of community forest, and available of off farm income (Gautam et al., 2003). Development of road network, emergence of market, and 
access to information lead to a radical agricultural transformation from traditional cereal based farming to modern cash crop farming in Ilam district of Eastern Nepal (Sharma, 1997; Chapagain, 2006). While in the case of the study area, it has been observed that there is continuous change in the land use land cover change in the study area. The result of household survey, KII and FGD show five major causes of land use change. Among them, growth of community forest is reported as the major driver of land use change followed by migration, labor shortage, natural calamities and infrastructure development (Table 5).

Table 5: Drivers of land use/ land cover change

\begin{tabular}{|c|c|c|c|c|c|c|}
\hline \multirow[b]{2}{*}{ Elevation } & \multicolumn{5}{|c|}{ Number of households reporting the drivers of land use change } & \multirow[b]{2}{*}{ Total } \\
\hline & $\begin{array}{l}\text { Growth of } \\
\text { community } \\
\text { forest }\end{array}$ & Migration & $\begin{array}{c}\text { Shortage of } \\
\text { agricultural } \\
\text { labor }\end{array}$ & $\begin{array}{c}\text { Natural } \\
\text { calamities }\end{array}$ & $\begin{array}{c}\text { Road } \\
\text { construction }\end{array}$ & \\
\hline Lower & 2 & 8 & 2 & 4 & 4 & 20 \\
\hline Middle & 17 & 3 & 8 & 4 & 3 & 35 \\
\hline Upper & 12 & 4 & 3 & 3 & 3 & 25 \\
\hline Total & 31 & 15 & 13 & 11 & 10 & 80 \\
\hline Percent & 38.8 & 18.8 & 16.3 & 13.8 & 12.5 & 100 \\
\hline
\end{tabular}

Source: Field survey, 2014

The development of community forest (CF) is the major cause of land use change especially in the upper part of the VDC. From 1996 to 2006, five CF have been registered and 816 hectares of previously cultivated land have been transformed to the CF (DFO, 2070/71 BS). Out of the total CF area, 773 hectares is from the upper part where people used to practice slash and burn agriculture for a long time. They used the land for the purpose of cultivating potato and grazing livestock. Migration has been another major cause of land use change as 19 percent households abandoned their agriculture land that caused land use change. Agriculture labor shortage is another major factor of land use change as reported by 16 percent households. Labor migration has resulted agriculture labor shortage. It is because of the labor shortage people have transformed cereal crops to cash crops i.e. cardamom which require less labor in comparision to cereal crops. Importantly, people have also transformed low productive land and in some cases good rain-fed terraces to private forest and started getting cash by selling logs (goliya).

Natural calamities such as landslide are also the driver of land use change. About 14 percent households have reported it as the major factor of land use change as it has occurred frequent landslide in the high slope areas that destroy crops. In such area both || $90 \|$ 
drought and fire damaged crops so that people have abandoned such land. Infrastructure such as road development has also leads to land use change. About 12 percent of the surveyed households have reported it as a major cause of land use change. Road has claimed agriculture, shrub and forest area and people have changed the land use of the area along the road to settlement.

\section{Conclusion}

Land use/land cover change is a dynamic phenomenon that takes place in space over time and it is thereby several human activities come into existence.The land use/land cover of Sidin VDC has undergone a drastic change during 1994-2014. Forest coverage has increased at the cost of agriculture, shrub and grassland. The introduction of cash crop mainly cardamom has contributed in land use change. The development of new infrastructure also leads to land use change as people of upper belt have migrated to lower belt along the road. With the development of road, people get access to market and thereby changes appears in agriculture pattern as they have started planting cash crops such as cardamom and also grow private forest where they used to cultivate cereal or left fallow in the past.

The initiation of community forest program positively help in increasing forest coverage especially in upper part and to the middle part of the VDC. Migration of households and involvement of youth to foreign labor migration, natural calamities and infrastructure development are found the major drivers of LULC change. It has also observed the tendency of migration towards lowland, along the river valley where both agriculture land and development of infrastructures are relatively better. There is decreasing trend of settlement and agricultural activities in the higher elevation on the one hand while on the other hand there is increasing settlement and concentration of different economic activities that has resulted faster land use land cover changes especially in middle and lower part of the VDC. It is thus, changing local demographic size, its structure, availability of off-farm income opportunities, state of infrastructure development and their location together with natural calamities are found the major drivers of LULC change.

\section{References}

Awasthi, K. D., Sitaula, B. K., Singh, B. R., \& Bajacharaya, R.M. (2002). Land-use change in two Nepalese watersheds: GIS and geomorphometric analysis.Land Degradation and Development, 13(6): 495-513. DOI: 10.1002/ldr.538 
Bajracharya, S., Maharjan, S., Shrestha, F., Bajracharya, O., \& Baidya, S. (2014). Glacier status in Nepal and decadal change from 1980 to 2010 based on Landsat data. Kathmandu:ICIMOD.

Bajracharya, D. (1983). Deforestation in the food/fuel context: historical and political perspectives from Nepal. Mountain Research and Development, 3(3): 227240.

CBS. (2012). National Population and Housing Census 2011 (National Report). Kathmandu: Central Bureau of Statistics, Nepal.

Chapagain, P. S. (2017).Contemporary readings in geography of Nepal. Kathmandu: Ekta Books Distributors Pvt. Ltd.

Chapagain, P. S. (2006). Involution or evolution?Conceptualizing the changes in farming system of eastern Nepal.The Himalayan Review, 37: 1-17.

Collins, R., \& Jenkins, A. (1996). The impact of agricultural land use on stream chemistry in the Middle Hills of the Himalayas, Nepal.Journal of Hydrology, 185(1): 7186.doi: 10.1016/0022-1694 (95)03008-5

DFO. (2070/2071 BS). Monitoring and evaluation of community forest, Panchthar district, (yearly report).Phidim: District Forest Office (DFO).

Eckholm, E. P. (1976). Losing ground: Environmental stress and world food prospects. New York: WW Norton.

Gao, J. (2012). Land cover change and its relationship with climate change in Koshi River Basin of central Himalaya. Institute of Geographic Sciences and Natural Resources Research, Graduate University of Chinese Academy of Sciences.

Gautam, A. P., Webb, E. L., Shivakoti, G. P. \& Zoebisch, M. A. (2003). Land use dynamics and landscape change pattern in a mountain watershed in Nepal. Agriculture, Ecosystems \& Environment, 99, (1-3):83-96. https://doi. org/10.1016/S0167-8809(03)00148-8.

Guillet, D. (1983). Toward a cultural ecology of mountains: The central Andes and the Himalayas compared. Current Anthropology, 24(5): 561-574.

Gurung, H. (2005). Landscape change in Lamjung: Evidence from Nepal hills. Kathmandu: ICIMOD.

Gurung, H. (1981). Ecological changes in Nepal: A native interpretation. An Occasional Paper 1. Kathmandu: New Era.

Gurung, H. B., \& Khanal, N. R. (1986-88). Landscape process in the Chure Range.The Himalayan Review, 17: 2-43. 
Ives, J. D., \& Messerli, B. (1989).Himalayan dilemma. New York: United Nations University Press.

Khanal, N. R. (2002). Land use and land cover dynamics in the Himalaya: A Case study of the Madi watershed, Western Development Region, Nepal. Tribhuvan University, Kirtipur, Nepal.

Khanal, N. R., \& Watanabe, T. (2006). Abandonment of agricultural land and its consequences.Mountain Research and Development, 26(1): 32-40.doi: http:// dx.doi.org/10.1659/0276-4741(2006)026[0032:AOALAI]2.0.CO;2

Koirala, H. (2017). Myth and reality of the eco-crisis in Nepal Himalaya. The Geographical Journal of Nepal, 10: 39-54. DOI: http://dx.doi.org/10.3126/gjn. v10i0.17389

Lambin, E. F., Rounsevell, M. D. A., \& Geist, H. J. (2000). Are agricultural land-use models able to predict changes in land-use intensity? Agriculture, Ecosystems \& Environment, 82(1-3): 321-331. doi: https://doi.org/10.1016/S01678809(00)00235-8

Mahat, T. B. S. (1985). Human impact on forests in the middle hills of Nepal. Unpublished $\mathrm{PhD}$ Dissertation, submitted to Australian National University, Canberra.

Paudel, K. P., Tamang S., \& Shrestha, K. K. (2014). Transforming land and livelihood: Analysis of agricultural land abandonment in the Mid Hills of Nepal. Journal of Forest and Livelihood, 12(1):11-19.

Paudel, N. S., Bastakoti, B. P., Karki, R., \& Bista, R. (2012). Drivers and dynamics of agrarian transformation in Nepal: Review of broader socio-economic issues around Nepalese agricultural development. Kathmandu: Forest Action Nepal.

Paudel, B., Gao, J., Zhang, Y., Wu, X., Li, S., \& Yan, J. (2016a). Changes in cropland status and their driving factors in the Koshi River basin of the Central Himalayas, Nepal.Sustainability, 8(9): 933; 1-17. doi: 10.3390/su8090933

Paudel, B., Zhang, Y., Li, S., Liu, L., Wu, X., \& Khanal, N. R. (2016b). Review of studies on land use and land cover change in Nepal. Journal of Mountain Science, 13(4): 643-660. doi: 10.1007/s11629-015-3604-9

Paudel, B., Zhang, Y., Li, S., \& Wu, X. (2017). Spatiotemporal reconstruction of agricultural land cover in Nepal from 1970 to 2010. Regional Environmental Change, 17(8): 2349-2357. doi: 10.1007/s10113-017-1164 
Rai, M. (2015). Land use/ land cover change and its causes: A case study of Sidin VDC, Panchthar district, Nepal. MA thesis, Central Department of Geography, TU, Kathmandu, Nepal.

Rimal, B., Baral, H., Stork, N. E., Paudyal, K., \& Rijal, S. (2015). Growing city and rapid land use transition: assessing multiple hazards and risks in the Pokhara Valley, Nepal. Land, 4:957-978. doi:10.3390/land4040957

Sharma, K. P., Vorosmarty, C. J., \& Moore Iii, B. (2000).Sensitivity of the Himalayan hydrology to land-use and climatic changes.Climatic Change, 47(1-2): 117139.doi: 10.1023/a:1005668724203

Sharma, P. (2003). Urbanization and Development.Population monograph of Nepal. Kathmandu: Central Bureau of Statistics. (pp. 375-412)

Sharma, S. (1997). Agricultural transformation processes in the mountains of Nepal: Empirical evidence from Ilam district. Kathmandu: ICIMOD.

Shrestha, B., \& Brown, S. (1995). Land use dynamics and intensification. Challenges in mountain resources management in Nepal: Processes, trends, and dynamics in middle mountain watersheds. Kathmandu:ICIMOD.

Steffen, W. L., Walker, B. H., Ingram, J. S., \& Koch, G. W. (1992).Global change and terrestrial ecosystems: The operational plan. IGBP report no 21. Stockholm: International Geosphere-Biosphere Programme.

Tamang, S., Paudel K. P., \& Shrestha, K. K. (2014). Feminization of agriculture and its implications for food security in rural Nepal. Journal of Forest and Livelihood 12(1):20-32.

Turner II, B. L., Skole, D., Sanderson, S., Fisher, G., Fresco, 1., \& Leemans, R. (1995). Land-use land-cover change science/research plan. IGBP global change report no 35 and HDP report no 7. Stockholm and Geneva: International GeosphereBiosphere Programme and the human dimension of global environmental change programme.

Virgo, K., \& Subba, K. (1994).Land-Use Change between 1978 and 1990 in Dhankuta District, Koshi Hills, Eastern Nepal.Mountain Research and Development, 14(2): 159-170.doi: $10.2307 / 3673798$

Vink, A. P. A. (1975). Land use is advancing agriculture. New York: Springer Verlag. 